\title{
The Effect of Mesoporous H-ZSM-5 Crystallinity as a CaO Support on the Transesterification of Used Cooking Oil
}

\author{
Amalia Putri Purnamasari, Meyga Evi Ferama Sari, Desy Tri Kusumaningtyas, \\ S. Suprapto, Abdul Hamid, Didik Prasetyoko* \\ Department of Chemistry, Faculty of Mathematics and Natural Science, Institut Teknologi \\ Sepuluh Nopember, Keputih, Sukolilo, Surabaya, 60111, Indonesia
}

Received: 21st November 2016; Revised: 8th March 2017; Accepted: 9th March 2017 Available online: 27th October 2017; Published regularly: December 2017

\begin{abstract}
Transesterification of used cooking oil was carried out over calcium oxide supported on mesoporous HZSM-5 prepared from kaolin as solid base catalysts. Solid basic catalysts investigated in this study were characterized by XRD, FTIR spectroscopy, and $\mathrm{N}_{2}$ adsorption-desorption techniques. The XRD pattern showed peaks corresponding to the $\mathrm{CaO}$ and mesoporous ZSM-5 in the sample. The peak intensity of the $\mathrm{CaO}$ increased as the $\mathrm{CaO}$ loading in ZSM-5 was increased. The characterization based on FTIR spectroscopy revealed that $\mathrm{CaO} / \mathrm{H}-\mathrm{ZSM}-5$ solids have functional groups characteristics of both $\mathrm{CaO}$ and mesoporous H-ZSM-5 which appeared in the band at around $550 \mathrm{~cm}^{-1}$ and $480 \mathrm{~cm}^{-1}$. The isotherm of $\mathrm{N}_{2}$ adsorption-desorption of $\mathrm{CaO} / \mathrm{H}-\mathrm{ZSM}-5$ indicated the type IV isotherm with the presence of hysteresis loop. For the catalytic activity, the biodiesel yield using catalyst of $10 \% \mathrm{CaO} / \mathrm{HZSM}-5$ (100 $\%$ ), $30 \%$ CaO/HZSM-5 (100 \%), $50 \%$ CaO/HZSM-5 (100\%) were 24.34, 27.37, and $29.73 \%$, respectively. It also related with the basic active site, when loading $\mathrm{CaO}$ increased, the basic active site also increased. Copyright (C) 2017 BCREC Group. All rights reserved
\end{abstract}

Keywords: CaO/H-ZSM-5; Zeolite; Mesoporous; Cooking Oil; Transesterification

How to Cite: Purnamasari, A.P., Sari, M.E.F., Kusumaningtyas, D.T., Suprapto, S., Hamid, A., Prasetyoko, D. (2017). The Effect of Mesoporous H-ZSM-5 Crystallinity as a CaO Support on the Transesterification of Used Cooking Oil. Bulletin of Chemical Reaction Engineering \& Catalysis, 12 (3): 329-336 (doi:10.9767/bcrec.12.3.802.329-336)

Permalink/DOI: https://doi.org/10.9767/bcrec.12.3.802.329-336

\section{Introduction}

The fuel consumption constantly rising from year to year. This is obvious because lately in Indonesia often scarcity of fuel oil, and even Indonesia has become the importer of petroleum. Therefore, it is necessary to develop alternative fuel sources. Biodiesel is a liquid fuel that recently studied as an alternative fuel because it has several advantages compared with diesel.

* Corresponding Author.

E-mail: didikp@chem.its.ac.id (Prasetyoko, D.)

Telp.: +62-31-5943353; Fax.: +62-31-5928314
It is mainly produced through the transesterification reaction of vegetable oils, which is a natural source of renewable and sustainable $[1,2]$. In the transesterification of vegetable oils, a triglyceride reacts with an alcohol in the presence of a strong acid or base, producing a mixture of fatty acids alkyl esters and glycerol [3]. Transesterification reaction can take place without using a catalyst, but it requires special conditions such that relatively long reaction time, high temperatures and pressures. Catalysts which have been used in the transesterification reaction is homogeneous and heterogeneous catalysts. However, the use of heterogeneous 
catalysts is more favorable than the homogeneous catalyst, because it is more environmentally friendly and easily separated from the product. Heterogeneous catalysts have been studied have a relatively high catalytic activity, but requires phase synthesis is complex and time-consuming. Thus, for further research to look for heterogeneous catalysts are an ideal, inexpensive, environmentally friendly in nature, and is effective for the transesterification reaction [4].

Among the heterogeneous catalysts studied, $\mathrm{CaO}$ has been considered a promising heterogeneous base catalyst for biodiesel production [59]. Alkali oxides $\mathrm{CaO}$ not only has a high alkalinity and activity, but also not soluble in methanol solvent medium in which the transesterification reaction [6]. To increase the catalytic activity, some research on supporting $\mathrm{CaO}$ material with a large surface area such as silica, alumina, and zeolite. Material support sustain good dispersion of the metal oxide so as to increase the surface area of the active site. Researcher [7] have done synthesis catalyst of $\mathrm{CaO} /$ mesoporous silica by impregnation method. Mesoporous silica has a surface area and large pore volume and has a uniform pore size. Calcium acetate, which has been impregnated in the mesoporous silica solids, distributed evenly on the surface of silica and filled the pores.

Referring to the previous studies, in this research, we have prepared CaO/H-ZSM-5 mesoporous using impregnation method with a variety of support (crystallinity of $64.41 ; 74.40$; and $100 \%)$ and $\mathrm{CaO}$ loading $(10 \%, 30 \%$, and $50 \% \mathrm{w} / \mathrm{w})$. Then, the catalysts were characterized and tested for the activity in the transesterification reaction.

\section{Materials and Methods}

\subsection{Materials}

The materials used in this study were mesoporous ZSM-5 (crystallinity of 64.41; 74.40; and $100 \%$ prepared from Indonesian kaolin based on our previous results with some modification [10], calcium acetate $\left(\mathrm{Ca}\left(\mathrm{CH}_{3} \mathrm{COO}\right)_{2} \cdot \mathrm{H}_{2} \mathrm{O}\right.$, Merck, 93-95 \%), ammonium acetate $\left(\mathrm{CH}_{3} \mathrm{COONH}_{4}\right.$, Merck, $\left.>98 \%\right)$, methanol $\left(\mathrm{CH}_{3} \mathrm{OH}\right.$, Merck $\left.99.9 \%\right)$, ethanol $\left(\mathrm{C}_{2} \mathrm{H}_{6} \mathrm{O}\right.$, Merck, $\left.99.9 \%\right)$, sodium hydroxide $(\mathrm{NaOH})$, toluena $\left(\mathrm{C}_{7} \mathrm{H}_{8}\right.$, Merck, $\left.99.9 \%\right)$, phenolphthalein (Merck), neutral red (Merck), 2,4dinitroaniline (Merck), 4-nitroaniline (Merck), nitrogen gas, and used cooking oil.

\subsection{Ion exchange}

Na-ZSM-5 solid was neutralized, dried, and calcined at a temperature of $550{ }^{\circ} \mathrm{C}\left(2^{\circ} \mathrm{C} / \mathrm{min}\right)$ with $\mathrm{N}_{2}$ flow for 1 hour followed by the flow of air for 6 hours to remove of the organic template. For cation exchange, 1 gram solid was refluxed with $50 \mathrm{~mL}$ of ammonium acetate $1 \mathrm{M}$ for 3 hours at $80{ }^{\circ} \mathrm{C}$. Then the solids was filtered and dried at $100{ }^{\circ} \mathrm{C}$ for 24 hours. The dried solid was continued for calcinations process at temperature of $550{ }^{\circ} \mathrm{C}$ for 5 hours in a tubular furnace $\left(2^{\circ} \mathrm{C} / \mathrm{min}\right)$.

\subsection{Preparation of catalyst $\mathrm{CaO} / \mathrm{H}-\mathrm{ZSM}-5$}

Three different kinds of support used in this study was the H-ZSM-5 with the crystallinity $64.41 ; 74.40$; and $100 \%$. The catalyst of CaO/H-ZSM-5 was synthesized by wet impregnation method and obtained through thermal decomposition. An amount of calcium acetate dissolved in distilled water was added to the solid H-ZSM-5. The $\mathrm{CaO}$ was dispersed on the support of H-ZSM-5 with a variation of the mass ratio CaO:H-ZSM-5, i.e. 10:100, 30:100 and 50:100 [5]. The mixture was stirred at 80 ${ }^{\circ} \mathrm{C}$ for 40 minutes using a magnetic stirrer. After the mixture was dried at $105{ }^{\circ} \mathrm{C}$ for 12 hours, the solid was then calcined at a temperature of $800{ }^{\circ} \mathrm{C}$ for 2 hours [11]. The activities of the $\mathrm{CaO} / \mathrm{H}-\mathrm{ZSM}-5$ catalyst was compared to the three support. Determining the effect of crystallinity support and the optimum loading were also conducted.

\subsection{Catalyst characterization}

Powder X-ray diffraction (XRD) patterns of the solids samples were collected on Philips X'pert XRD instrument with $\mathrm{Cu} \mathrm{Ka}$ radiation with a step size of $0.04^{\circ}$ and counting time of $10 \mathrm{~s}$. The samples were grinded in agate mortar before analysis. The data were recorded in the $2 \theta$ range of $5-70^{\circ}$. Fourier transform infrared (FTIR) spectra of the samples were recorded on a Shimadzu spectrophotometer using the $\mathrm{KBr}$ pellet technique, in the range of $400-4000 \mathrm{~cm}^{-1}$. Nitrogen adsorption-desorption were recorded on Adsorption-Desorption Nitrogen Quantachrome Instruments with measured at $77 \mathrm{~K}$ after pretreatment at $673 \mathrm{~K}$ for $4 \mathrm{~h}$ under vacuum. The total surface area was determined by the BET method, the total pore volume was obtained as the amount of nitrogen adsorbed at $\mathrm{P} / \mathrm{P}_{0}$ of 0.99 , and the $t$-pot method was used to distinguish micropores from mesopores. 


\subsection{Catalytic activity}

Transesterification reaction was carried out with reflux method. Three-neck-round-bottomflask was placed on an oil bath equipped with temperature controller, magnetic stirrer and reflux condenser. The reaction temperature in this system was $65^{\circ} \mathrm{C}$ with methanol to oil molar ratio of $12: 1$ and $2 \% \mathrm{w} / \mathrm{w}$ catalyst.

The catalyst of $\mathrm{CaO} / \mathrm{H}-\mathrm{ZSM}-5$ was mixed with methanol in a round bottom flask connected to a condenser which is placed in the bath with the reaction temperature of $65^{\circ} \mathrm{C}$. The oil has also been heated at a temperature of $65{ }^{\circ} \mathrm{C}$. The mixture was stirred using a magnetic stirrer at constant speed for 2 hours. To stop the reaction, the mixture was immersed in a container of water at room temperature and the catalyst was separated from the product using a centrifuge at $6000 \mathrm{rpm}$ for 30 minutes.

Transesterification product was transferred to a separating funnel and allowed to stand overnight to completely phase separates glycerol and biodiesel. Glycerol phase (bottom layer) separated in advance, after the biodiesel phase (top layer) was washed with warm distilled water to remove residual glycerol. Then, the remaining water and methanol were evaporated at $105{ }^{\circ} \mathrm{C}$ for 2 hours to obtain biodiesel with high purity [11].

\subsection{Determination of FAME (Fatty Acid Methyl Ester) content}

Biodiesel synthesis product was characterized by Gas Chromatography (GC) to determine the extent of the area so that it can be calcu-

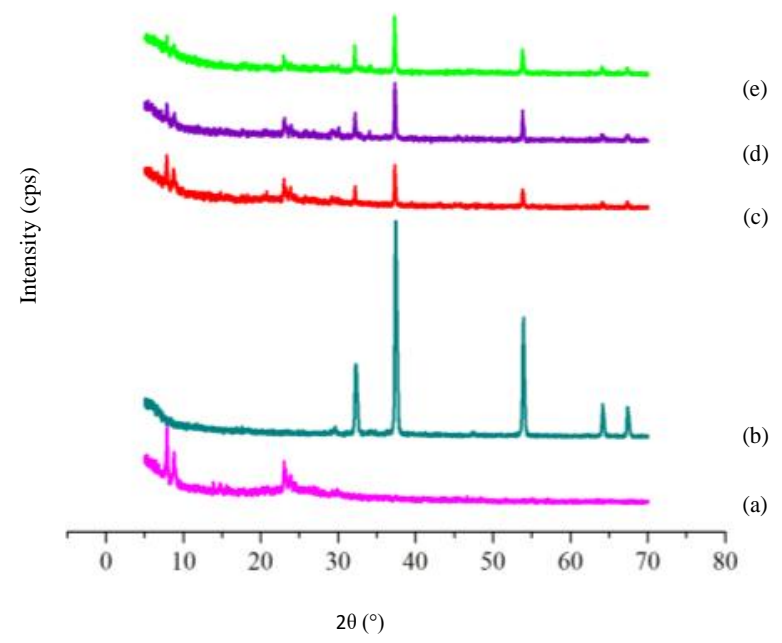

Figure 1. XRD patterns of catalyst samples: (a) ZSM-5 (64.41\%), (b) $\mathrm{CaO}$, (c) $10 \% \mathrm{CaO} / \mathrm{H}-$ ZSM-5, (d) $30 \%$ CaO/H-ZSM-5， (e) $50 \%$ $\mathrm{CaO} / \mathrm{H}-\mathrm{ZSM}-5$ lated methyl ester concentration. Then the value of these concentrations can be used to calculate the yield of biodiesel as stated in Equation (1) [3].

$$
\text { Yield }=\frac{W_{B} / C_{I}}{W_{A}} \times C_{\text {Tot }} \times 100 \%
$$

where, $W_{B}$ denotes mass of biodiesel (g), $C_{I}$ is biodiesel concentration (ppm), $W_{A}$ symbolizes mass of oil (g), and $C_{t o t}$ is concentration of methyl ester (ppm).

\section{Results and Discussion}

\subsection{Characterization of catalyst}

X-ray diffraction technique was used for phase identification of samples ZSM-5, CaO, and $\mathrm{CaO} / \mathrm{H}-\mathrm{ZSM}-5$ with different of loading $\mathrm{CaO}$ and crystallinity of ZSM-5 itself. The results of the XRD diffractogram $2 \theta\left(^{\circ}\right)$ of 5-70 samples are shown in Figures (1)-(3). The XRD patterns of mesoporous ZSM- 5 samples showed peaks at $2 \theta\left({ }^{\circ}\right)$ of $7.99 ; 8.86 ; 23.14 ; 23.98$; and 24.48, corresponding to the MFI structure of the crystal, as reported by Goncalves et al. [12]. Meanwhile, the XRD patterns of $\mathrm{CaO}$ samples showed peaks at $2 \theta\left(^{\circ}\right)$ of $32.21 ; 37.38 ; 53.87$; 64.15; and 67.37, which are characteristic of crystalline peaks of $\mathrm{CaO}$ from thermal decomposition of calcium acetate. The XRD pattern of $\mathrm{CaO}$ was similar to the results reported [13]. The peaks of the XRD patterns of mesoporous ZSM-5 and $\mathrm{CaO}$ samples were appeared on all $\mathrm{CaO} / \mathrm{H}-\mathrm{ZSM}-5$ samples, indicated that the samples contains $\mathrm{CaO}$ crystals and ZSM-5.

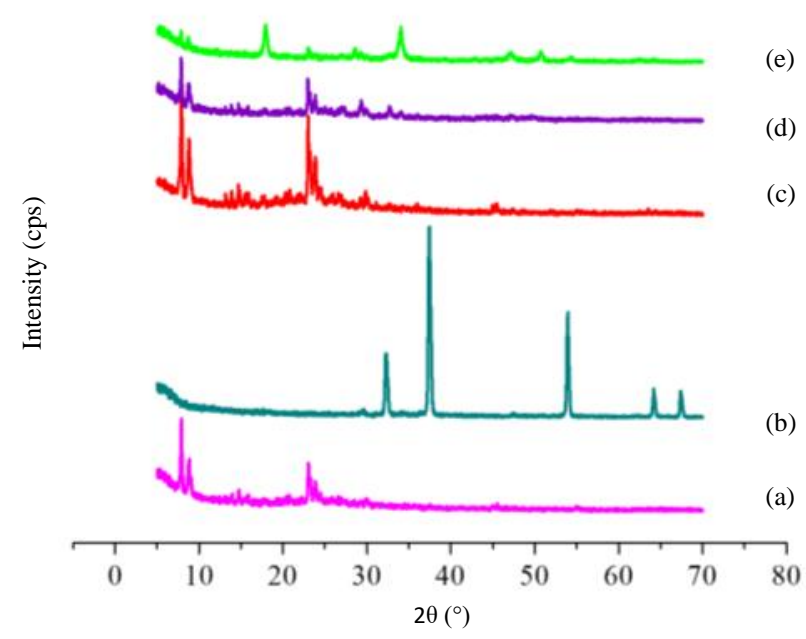

Figure 2. XRD patterns of catalyst samples: (a) ZSM-5 (74.40\%), (b) $\mathrm{CaO}$, (c) $10 \% \mathrm{CaO} / \mathrm{H}$ ZSM-5, (d) $30 \%$ CaO/H-ZSM-5, (e) $50 \%$ $\mathrm{CaO} / \mathrm{H}-\mathrm{ZSM}-5$ 
However, the sample of $10 \% \mathrm{CaO} / \mathrm{H}-\mathrm{ZSM}-5$, $30 \% \mathrm{CaO} / \mathrm{H}-\mathrm{ZSM}-5$ and $50 \% \mathrm{CaO} / \mathrm{H}-\mathrm{ZSM}-5$ shows the differences at peaks intensity. Overall, the XRD pattern shows that as loading of $\mathrm{CaO}$ in ZSM-5 increased, $\mathrm{CaO}$ peaks intensity becomes higher than the peaks intensity of ZSM-5. XRD peak intensity related to the concentration of $\mathrm{CaO}$ and mesoporous ZSM-5 in the sample. High concentrations have resulted in high peak intensity in the diffraction lines. Similar finding has been reported by Pasupulety et al. [13] that the increased of Ca loading on $\mathrm{Al}_{2} \mathrm{O}_{3}$, the peak intensity of $\mathrm{CaO}$ will also be increased.

Characterization by FTIR spectroscopy was aimed to the identification of functional groups on the samples. Figure 4 shows the infrared spectra of the samples, i.e. 10,30 , and $50 \%$ of the CaO/H-ZSM-5 (100 \%). Peak at $917 \mathrm{~cm}^{-1}$ is $\mathrm{Al}-\mathrm{OH}$ vibration, while the peaks at $1107 \mathrm{~cm}^{-1}$ is the vibration of in plane $\mathrm{Si}-\mathrm{O}$ stretching. The appearance of the peaks at 1090, 796, and 450 $\mathrm{cm}^{-1}$ were characteristic of the silica-based materials framework. The shoulder peaks at $1220 \mathrm{~cm}^{-1}$ was assigned to the external asymmetry stretching of $\mathrm{Si}-\mathrm{O}-\mathrm{Si}$ bond and the peak at $960 \mathrm{~cm}^{-1}$ was attributed to the terminal silanol groups ( $\mathrm{Si}-\mathrm{OH})$ on the wall surface of the mesopores. The absorption band at $548 \mathrm{~cm}^{-1}$ was the characteristics of the five ring unit in pentasil structure such as ZSM-5 zeolite. The $\mathrm{CaO}$ samples showed $\mathrm{OH}$ band at wavenumber of about $3600 \mathrm{~cm}^{-1}$, $\mathrm{CH}$ band at $2300-2900 \mathrm{~cm}^{-1}$, $\mathrm{CO}$ band in the wavenumber around 1400,

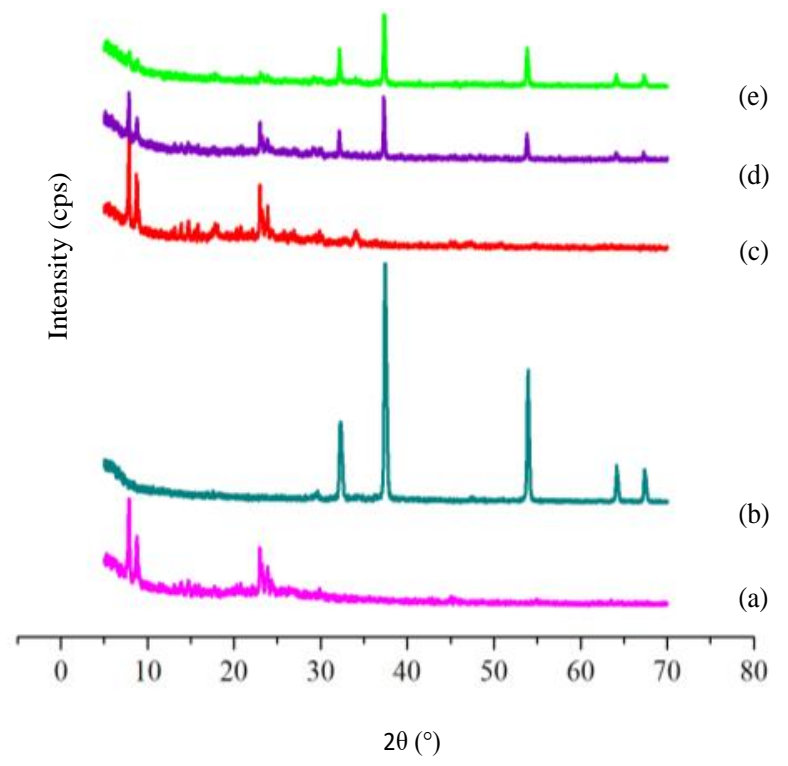

Figure 3. XRD pattern of samples: (a) ZSM-5 (100\%), (b) $\mathrm{CaO}$, (c) $10 \% \mathrm{CaO} / \mathrm{H}-\mathrm{ZSM}-5$, (d) 30 $\% \mathrm{CaO} / \mathrm{H}-\mathrm{ZSM}-5$, (e) $50 \% \mathrm{CaO} / \mathrm{H}-\mathrm{ZSM}-5$
1700 , and $875 \mathrm{~cm}^{-1}$, as well as on the absorption band of $\mathrm{CaO}$ on the wavenumber around $400 \mathrm{~cm}^{-1}$ [14]. Meanwhile, samples with impregnation method showed a specific absorption band which is a combination of an absorption band samples of ZSM- 5 and $\mathrm{CaO}$, but with different intensities depending on the loading of $\mathrm{CaO}$. At the higher $\mathrm{CaO}$ loading, the intensity of the absorption band $\mathrm{CaO}$ in the $\mathrm{CaO} / \mathrm{H}-\mathrm{ZSM}-5$ sample also increased. These intensity of the bands are related to the concentration of $\mathrm{CaO}$ and ZSM-5 in the sample. The result of FTIR analysis supported of the XRD data.

The $\mathrm{N}_{2}$ adsorption-desorption of the solid products have been carried out to determine specific surface area, the pore size distribution, the total pore volume, and the pore structure of the materials [12]. The $\mathrm{N}_{2}$ adsorptiondesorption isotherms of $\mathrm{CaO}$ impregnated ZSM- 5 with a variation of Ca loading of 10, 30, and $50 \%(\mathrm{w} / \mathrm{w})$ are shown in Figure 5. The $\mathrm{N}_{2}$ adsorption-desorption isotherm of the $\mathrm{CaO} / \mathrm{H}-\mathrm{ZSM}-5$ indicates the type IV isotherm with the presence of hysteresis loop $\left(\mathrm{P} / \mathrm{P}_{0}\right.$ of 0.3-1.0) due to the capillary condensation processes, which is a characteristic of mesoporous material. The micropore and mesopore surface area calculated from the isotherms data are given in Table 1. The BET surface area of $10 \%$ CaO/H-ZSM-5 (100 \%) is $159.737 \mathrm{~m}^{2} / \mathrm{g}$, while $t$ plot micropore and mesopore surface area are $102.787 \mathrm{~m}^{2} / \mathrm{g}$ and $56.950 \mathrm{~m}^{2} / \mathrm{g}$, respectively. Table 1 summarized the physical characteriza-

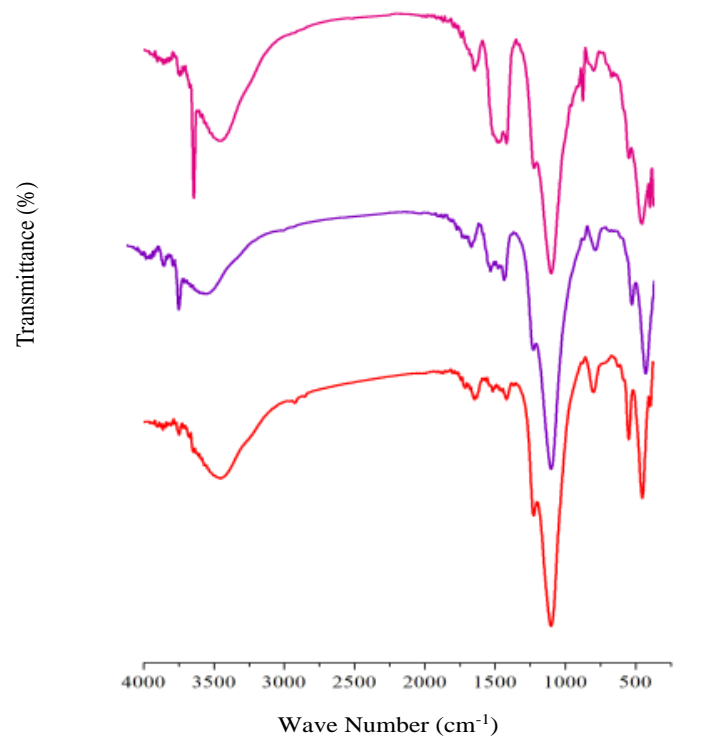

(c)

(b)

Figure 4. Infrared spectra of samples: (a) $10 \%$ CaO/H-ZSM-5 (100 \%), (b) $30 \%$ CaO/H-ZSM-5 (100 \%), (c) $50 \%$ CaO/H-ZSM-5 (100\%) 
tion of the $\mathrm{CaO} / \mathrm{H}-\mathrm{ZSM}-5$ catalyst calculated from the analysis of $\mathrm{N}_{2}$ adsorption-desorption data. The specific surface area of the CaO/HZSM-5 catalyst decreases significantly when the loading $\mathrm{Ca}$ extended from $30 \%$ to 50 $\%$. This results are consistent with the previous results [15] that $\mathrm{CaO}$ was uniformly dispersed in SBA-15, as therefore, the higher loading of Ca causes a drastic decreased in surface area.

\subsection{Catalytic activity}

All CaO/H-ZSM-5 samples were examined as catalyst in the transesterification of waste cooking oil with methanol. Based on calcula-

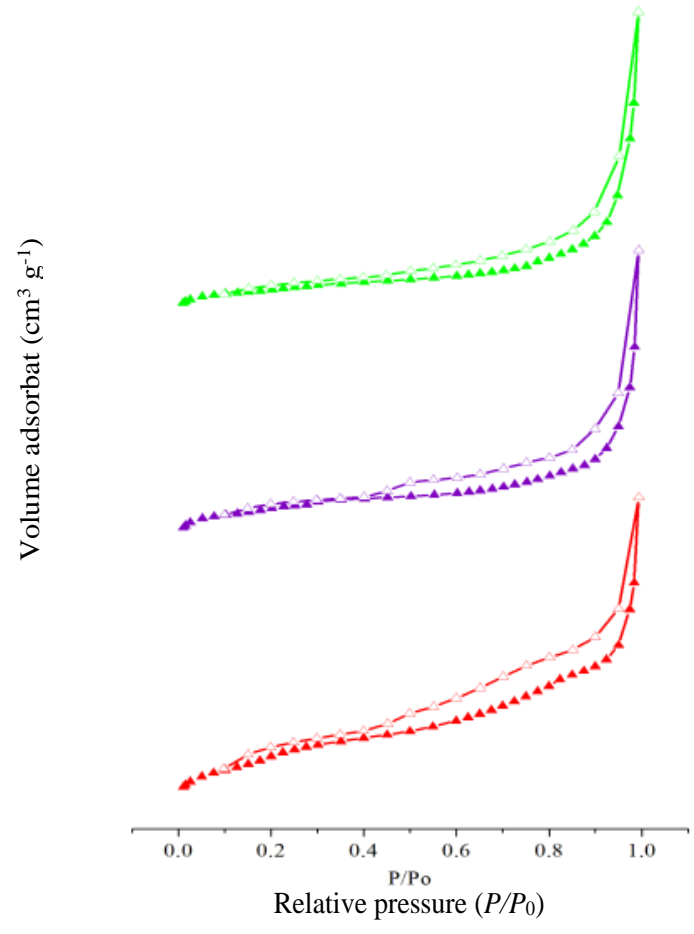

(c)

(b)

(a)

Figure 5. $\mathrm{N}_{2}$ adsorption-desorption isotherms: (a) $10 \% \mathrm{CaO} / \mathrm{H}-\mathrm{ZSM}-5(100 \%)$, (b) $30 \%$ $\mathrm{CaO} / \mathrm{H}-\mathrm{ZSM}-5(100 \%)$, (c) $50 \% \mathrm{CaO} / \mathrm{H}-\mathrm{ZSM}-$ $5(100 \%)$ tions yield of biodiesel, it is known that the yield of biodiesel produced increased in accordance with the increase of the $\mathrm{CaO}$ catalyst loading. The $\mathrm{CaO}$ were dispersed on the support of crystalline H-ZSM-5, i.e. the $10 \%$ CaO/H-ZSM-5 (100 \%) catalyst produced biodiesel with the yield of $24.34 \%$. The biodiesel yield showed a slight increase with the use of a catalyst of $30 \% \mathrm{CaO} / \mathrm{H}-\mathrm{ZSM}-5$ (100 \%) with the yield of $27.37 \%$. Meanwhile, the catalyst of $50 \% \mathrm{CaO} / \mathrm{H}-\mathrm{ZSM}-5$ (100\%) produced biodiesel yield of $29.73 \%$. These finding related to the basic active site, in which at loading $\mathrm{CaO}$ increases, the basic active site increased. The correlation between loading $\mathrm{CaO}$ with the yield is shown in Figure 6.

Loading $\mathrm{CaO}$ also affect the pore volume of the catalyst. The higher loading $\mathrm{CaO}$, the pores full filled by the basic active site. In the reaction between oil and methanol, the catalyst provides sufficient adsorption sites for methanol, so that $\mathrm{O}-\mathrm{H}$ bond of methanol broke out

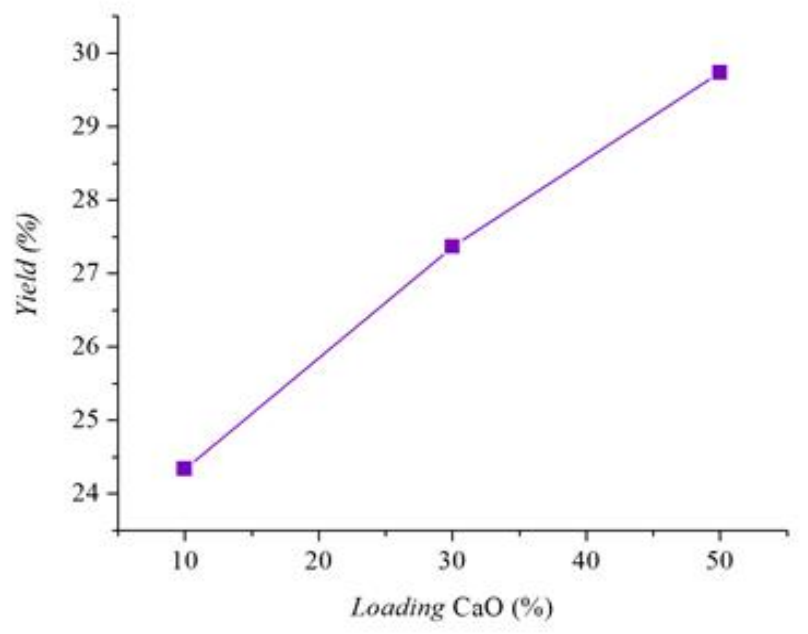

Figure 6. Correlation between $\mathrm{CaO}$ loading (CaO/H-ZSM-5 $100 \%$ ) with yield

Table 1. Surface area, pore volume and pore diameter of sample CaO/H-ZSM-5

\begin{tabular}{ccccccccc}
\hline Sample & $\begin{array}{c}\mathrm{S}_{\mathrm{BET}}{ }^{\mathrm{a}} \\
\left(\mathrm{m}^{2} / \mathrm{g}\right)\end{array}$ & $\begin{array}{c}\mathrm{S}_{\text {meso }}{ }^{\mathrm{d}} \\
\left(\mathrm{m}^{2} / \mathrm{g}\right)\end{array}$ & $\begin{array}{c}\mathrm{S}_{\text {micro }}{ }^{\mathrm{b}} \\
\left(\mathrm{m}^{2} / \mathrm{g}\right)\end{array}$ & $\begin{array}{c}\mathrm{V}_{\text {meso }^{\mathrm{b}}} \\
\left(\mathrm{cm}^{3} \mathrm{~g}^{-1}\right)\end{array}$ & $\begin{array}{c}\mathrm{V}_{\text {micro }}{ }^{\mathrm{b}} \\
\left(\mathrm{cm}^{3} \mathrm{~g}^{-1}\right)\end{array}$ & $\begin{array}{c}\mathrm{V}_{\text {total pore }^{\mathrm{c}}} \\
\left(\mathrm{cm}^{3} \mathrm{~g}-1\right)\end{array}$ & $\begin{array}{c}\mathrm{D}_{\text {meso }} \\
(\mathrm{nm})^{\mathrm{d}}\end{array}$ & $\begin{array}{c}\mathrm{D}_{\text {micro }} \\
(\mathrm{nm})\end{array}$ \\
\hline $10 \% \mathrm{CaO}(100 \%)$ & 159.737 & 56.950 & 102.787 & 0.166 & 0.058 & 0.224 & 3.82 & 0.35 \\
$30 \% \mathrm{CaO}(100 \%)$ & 105.487 & 34.268 & 71.219 & 0.152 & 0.043 & 0.195 & 3.82 & 0.45 \\
$50 \% \mathrm{CaO}(100 \%)$ & 57.016 & 24.814 & 32.202 & 0.147 & 0.022 & 0.169 & 3.82 & 0.45 \\
\hline
\end{tabular}

${ }^{a}$ S

${ }^{\mathrm{b}} \mathrm{S}_{\text {micro }}$ (micropore surface areas), Vmeso (mesopore volume), $\mathrm{V}_{\text {micro }}$ (micropore volume) by $t$-plot method

cAdsorbate volume at $\mathrm{P} / \mathrm{P}_{0} 0.99$

d $\mathrm{S}_{\text {meso }}$ (mesopore surface areas), $\mathrm{D}_{\text {meso }}$ (mesopore diameter or distribution) by BJH method

e $\mathrm{D}_{\text {micro }}$ (micropore diameter or distribution) by SF method 


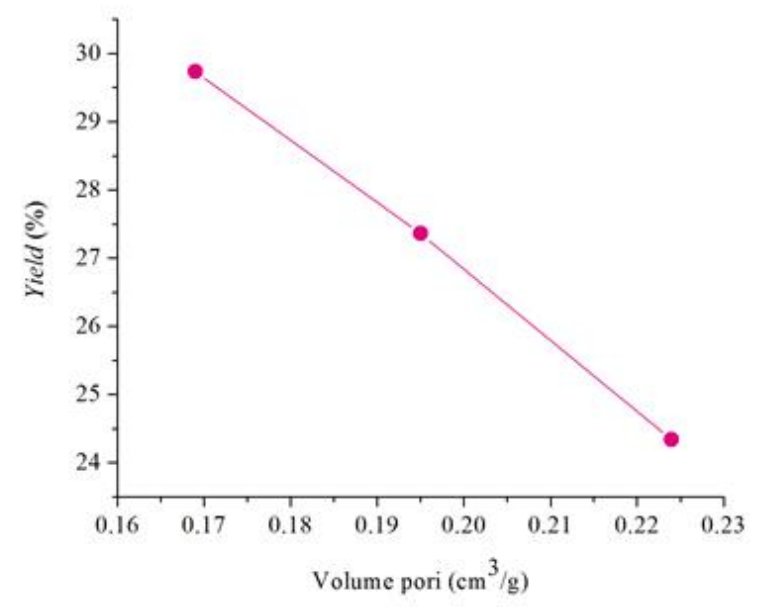

Figure 7. Correlation between loading $\mathrm{CaO}$ (CaO/H-ZSM-5 $100 \%$ ) with biodiesel yield

forming $\mathrm{CH}_{3} \mathrm{O}^{-}$and $\mathrm{H}^{+}$ions. Then the $\mathrm{CH}_{3} \mathrm{O}$ ions reacts with triglyceride molecule to form biodiesel. Thus, the more active site of the base catalyst, the more ions $\mathrm{CH}_{3} \mathrm{O}$ - formed, as therefore, the conversion of triglyceride is also increased. The catalyst resulted the highest biodiesel yield in this reaction is $50 \% \mathrm{CaO} / \mathrm{H}$ ZSM-5 (100\%). The correlation between loading $\mathrm{CaO}$, pore volume, and biodiesel yield are shown in Figure 7.

\section{Conclusions}

Preparation and characterization of $\mathrm{CaO} / \mathrm{H}-\mathrm{ZSM}-5$ has been studied using XRD, FTIR, and $\mathrm{N}_{2}$ adsorption-desorption techniques. On the basis of the results, as the addition of $\mathrm{CaO}$ increases, the intensity of $\mathrm{CaO}$ diffraction line was increased, while specific surface area and pore diameter were decreased. FTIR spectroscopy showed the characteristics peaks of $\mathrm{CaO}$ and mesoporous ZSM-5. Characterization by $\mathrm{N}_{2}$ adsorption-desorption showed that the impregnation of $\mathrm{CaO}$ on mesoporous ZSM-5 did not only caused pore blocking and filling, but also decreasing of the surface area of mesoporous catalyst. For the catalytic activity of $\mathrm{CaO} / \mathrm{H}-\mathrm{ZSM}-5$ in the transesterification reaction of used cooking oil, biodiesel was produced in higher yields with increased of $\mathrm{CaO}$ loading for catalyst CaO/H-ZSM-5 (100\%).

\section{Acknowledgement}

The author greatly thanks to the Ministry of Research and Higher Education, Indonesia under "PUPT 2015-2016".

\section{References}

[1] Kansedo, J., Lee, K.T., Bhatia, S. (2009). Cerbera Odollam (Sea Mango) Oil as A Promising Non-Edible Feedstock for Biodiesel Production. Fuel, 88: 1148-1150.

[2] Holilah, Prasetyoko, D., Oetami, T.P., Santosa, E.B., Zein, Y.M., Bahruji, H., Ediati, R.,Fansuri, H., Juwari. (2015). The Potential of Reutealis Trisperma Seed as A New NonEdible Source for Biodiesel Production. Biomass Conversion and Biorefinery, 5: 347-353.

[3] Wang, Y., Chou, H., Chen, B., Lee, D. (2013). Optimization of Sodium Loading on Zeolite Support for Catalyzed Transesterification of Triolein with Methanol. Bioresource Technology, 145: 1-6.

[4] Yan, S., Lu, H., Liang, B. (2008). Supported $\mathrm{CaO}$ Catalysts Used in the Transesterification of Rapeseed Oil for the Purpose of Biodiesel Production. Energy \& Fuels, 22: 646651.

[5] Witoon, T., Bumrungsale, S., Vathavanichkul, P., Palitsakun, S., Saisriyoot, M., Faungnawakij, K. (2014). Biodiesel Production from Transesterification of Palm Oil with Methanol over $\mathrm{CaO}$ Supported on Bimodal MesoMacroporous Silica Catalyst. Bioresource Technology, 156: 329-334.

[6] Samart, C., Chaiyan, C., Reubroycharoen, P. (2010). Biodiesel Production by Methanolysis of Soybean Oil Using Calcium Supported on Mesoporous Silica Catalyst. Energy Conversion and Management, 51: 1428-1431.

[7] Zabeti, M., Daud, W., Aroua, M.K. (2010). Biodiesel Production Using AluminaSupported Calcium Oxide: An Optimization Study. Fuel Processing Technology, 91: 243248.

[8] Demirbas, A. (1998). Fuel Properties and Calculation of Higher Heating Values of Vegetable Oils. Fuel, 771: 117-120.

[9] Schuchardt, U., Sercheli, R., Vargas, R.M. (1998). Transesterification of Vegetable Oils: A Review. Brazilian Chemical Society, 9: 199210.

[10] Qoniah, I., Prasetyoko, D., Bahruji, H., Triwahyono, S., Jalil, A.A., Suprapto, Hartati, Purbaningtyas, T.E. (2015). Direct Synthesis of Mesoporous Aluminosilicates from Indonesian Kaolin Clay without Calcinations. Applied Clay Science, 118: 290-294.

[11] Zein, Y.M., Anal, A.K., Prasetyoko, D., Qoniah, I. (2016). Biodiesel Production from Waste Palm Oil Catalyzed by Hierarchical ZSM-5 Supported Calcium Oxide. Indonesian Journal of Chemistry, 16: 98-104. 
[12] Gonçalves, M.L., Dimitrov, L.D., Jordão, M.H., Wallau, M., Urquieta-González, E.A. (2008). Synthesis of Mesoporous ZSM-5 by Crystallisation of Aged Gels in the Presence of Cetyltrimethylammonium Cations. Catalysis Today, 133-134: 69-79.

[13] Pasupulety, N., Gunda, K., Liu, Y., Rempel, G.L., Flora, T.T.Ng. (2013). Production of Biodiesel from Soybean Oil on $\mathrm{CaO} / \mathrm{Al}_{2} \mathrm{O}_{3}$ Solid Base Catalysts. Applied Catalysis A General, 452: 189-202.
[14] Granados, M.L., Poves, M.D.Z., Alonso, D.M., Mariscal, R., Galisteo, F.C., Moreno-Tost, R. (2007). Biodiesel from Sunflower Oil by Using Activated Calcium Oxide. Applied Catalysis B: Environmental, 73: 317-326.

[15] Albuquerque, M.C.G., Jimenez-Urbistonde, I., Santamaria-Gonzalez, J., Merida-Robles, J.M., Moreno-Tost, R., Rodriguez-Castellon, E., Jimenez-Lopez, A., Azevedo, D.C.S., Cavalcante Jr, C.L., Maireles-Torres, P. (2008). CaO Supported on Mesoporous Silicas as Basic Catalysts for Transesterification Reactions. Applied Catalyst A General, 334: 3543.

Selected and Revised Papers from The $2^{\text {nd }}$ International Seminar on Chemistry (ISoC 2016) (Surabaya, 26-27 July 2016) (http://chem.its.ac.id/isoc-2016/) after Peer-reviewed by Scientific Committee of ISoC 2016 and Peer-Reviewers of BCREC journal 